\title{
Literary Translation, Translating Culture: The Case of Shahriyar, the Famous Iranian Azeri Poet
}

\author{
Sajjad Kianbakht \\ IAU, South Tehran Branch, Tehran, Iran \\ E-mail: Sajjad.Kianbakht@gmail.com
}

Doi:10.7575/aiac.alls.v.7n.4p.239

URL: http://dx.doi.org/10.7575/aiac.alls.v.7n.4p.239
Received: 24/04/2016

Accepted: 28/06/2016

\begin{abstract}
A literary translation is a device of art used to release the text from its dependence on prior cultural knowledge (Herzfeld, 2003). The present research investigates the use of pragmatic equivalence in two translations of the Azeri Turkish long poem "Haydar Bābāye Salām" by "Shahriyar". Based on Koller's theory of equivalence (2001) four elements were assigned for the pragmatic equivalence: 1) domestication rather than foreignization, 2) naturalness of the expressions, 3) focus on target-text reader, and 4) content-based product. Thirty six stanzas from the initial, middle and final part of the poem were selected and then their two translations were analyzed according to the aforementioned elements. Moreover, based on Newmark's model (1988) it is also investigated that whether a translation with all the four elements of pragmatic equivalence is a good one or not. According to Newmark's model (1988) three markers of a good translation are: 1) utilization of pragmatic equivalence, 2) naturalness, and 3) not sounding like a translation. The results suggest that a translator who has utilized all the elements of pragmatic equivalence is also successful in reproducing a better translation for the target language readers.
\end{abstract}

Keywords: Equivalence theory, Literary translation, Poetry translation, Pragmatic equivalence

\section{Introduction}

Literary translation especially translation of poetry is one of the most challenging kinds of translation. This is due to the various challenging aspects characteristics of the poetry like: rhythm, rhyme, meter and other literary devices as well as certain cultural elements which are usually different from the source to the target language. One of the most fundamental prerequisites of the art of literary translation is the translator's comprehensive competence in the source and target languages and literatures. Furthermore, cultural transfer as another substantial aspect of literary translation plays a crucial role in translation of the poetry. This unique type of translation is not only recognized as an academic field of study but also has always been perceived and practiced in a variety of manners and styles through a variety of literary traditions.

Considering the above mentioned notions, the utilization of the pragmatic equivalence in two Persian translations of the long poem "Haydar Bābāye Salām" by Shahriyar is the subject of the present research. The poet is undoubtedly known as one of the famous Iranian poets of the 20th century. His masterpiece poem has 76 stanzas; each composed of 5 lines. The researcher has randomly selected twelve stanzas from the beginning, another twelve stanzas from the middle and finally twelve other stanzas from the final part of the poem. Therefore, overall 36 stanzas were studied and analyzed in this research.

\section{A Brief Literature Review}

\subsection{Overview}

In this part the research, first of all a brief introduction to Azeri Turkish Language in Iran was given, then a brief insight to Shahriyar and his poem "Haydar Bābāye Salām" was demonstrated and finally for the purpose of the present research I embarked upon the explication of the notion of equivalence in translation.

\subsection{Azeri Turkish Language in Iran}

Azerbaijan also known as Iranian Azerbaijan is an area in northwestern Iran. It is historically known as Atropatene and Aturpatakan. Iranian Azerbaijan generally encompasses the northwest provinces of Iran including East and West Azerbaijan, Ardabil, Zanjan and some parts of Hamadan and Qazvin. It shares borders with the Republic of Azerbaijan, Armenia, Turkey, and Iraq. Azerbaijan is famous for its conspicuous nature and Shahriyar's masterpiece poem "Haydar Bābāye Salām" is inspired from this marvelous nature.

"Azeri Turkish is spoken by about one third of the total population of the country in Iran plus by eight and half million people in the Republic of Azerbaijan where it is the official language" (Ahmadian, 2010, p.12). Azeri Turkish is a Turkic language, similar to, but not the same as Turkey's Turkish. It is also different from Persian, Iran's official language. 
Throughout the most of its history, Azeri Turkish literature has been divided into two rather different traditions, neither of which exercised much influence upon the other until the 19th century. The first of these traditions is Azeri Turkish folk literature, and the second is Azeri Turkish written literature. Shahriyar's poem "Haydar Bābāye Salām" as one of those outstanding Azeri Turkish written literature is the subject of the present research.

\subsection{Shahriyar and "Haydar Bābāye Salām"}

"Haydar Bābāye Salām" (Greetings to Haydar Bābā) is an influential piece of post-World War II Azeri poetry, written by Azeri famous poet Mohammad Hossein Behjat Tabrizi (1906-1988), under the pen name of Shahriyar, who had already established himself as an outstanding Persian poet.

He was born in Tabriz in September 18, 1906; however, he had spent most of his youth in the village of Khoshknab. Probably, he has owed his affection to the nature as well as his unique poetic talent to this village.

His first literary works were published in Tehran in 1926. Shahriyar was also the first Iranian to compose significant poetry in Azeri. He published his first book of poems with prefaces by a couple of famous Persian poets like: Mohammad Taghi Bahar, Saeed Nafisi and Pezhman Bakhtiar. His poems are mainly influenced by Hafez and his most famous Azeri poem "Haydar Bābāye Salām" is considered among the best modern poems in the language and literature and has successfully been transformed into a few plays.

Many of Shahriyar's sweet memories are reflected in his book "Haydar Bābā,"which is the name of a mountain near his birthplace where he spent most of his childhood. It is composed in Azeri Turkish language and later translated into Persian as well as many other languages throughout the world. His book was among the top ten best-seller list for quite a long time in Iran.

Since it became popular among the Azeri people and even among people of other languages, Shahriyar decided to compose the second series of "Haydar Bābāye Salām." Shahriyar has composed his poems in syllabic meter with the pattern of $4+4+3$.

The first "Haydar Bābāye Salām" includes 76 stanzas and the second one is composed of 49 stanzas. Each stanza consists of five lines that the first three ones have the same rhyme, and the last two ones are different. Although this great literary masterpiece is translated into many languages, but for certain reasons its translation is a difficult and challenging endeavor. The description of cultural traditions of the poet's birthplace and frequently used proper names as well as the use of the local and culture-specific elements are among the difficulties faced by the translators.

\subsection{Equivalence in Translation}

The main purpose of this part is to explain the concept of equivalence in translation. More specifically, one of the most prominent issues in translation process which requires a sort of systematic analysis of translation is the concept of meaning and 'equivalence' (Munday, 2001, p.35). Overall, the process of finding equivalents in two languages consists of two general phases: first, the translator should decode the source text (ST) to figure out the meaning/ message/intention of the original author and then he should try to encode the same meaning/message/intention in the target text (TT). According to Koller (1989), equivalence has five different types which are: 1) Denotative equivalence, 2) Connotative equivalence, 3) Text-normative equivalence, 4) Formal equivalence and finally 5) Pragmatic equivalence, which is the main focus of the present study.

Pragmatic equivalence, which is the central theme of the present research, was first proposed by Koller in 1989. According to Koller (1989) pragmatic equivalence or communicative equivalence is oriented towards the receiver of the text or the message and therefore focuses mainly on the communication principle. This is similar to Nida's dynamic equivalence (1964) which "is based on what Nida calls 'the principle of equivalent effect', where the relationship between receptor and message should be substantially the same as the one existed between the original receptors and the message" (Munday, 2001, p.42).

To sum up, pragmatic equivalence is given priority in this research since it tries "to analyze the communicative conditions valid for different receiver groups in different language pairs and texts" (Munday, 2001, p.48). Therefore, we may claim that it plays an essential role in the field of literary translation.

Considering the above mentioned notions, the utilization of the pragmatic equivalence in two Persian translations of the long poem "Haydar Bābā ye Salām" by Shahriyar is the subject of the present research.

\section{Methodology}

\subsection{Overview}

The present research investigates the use of pragmatic equivalence in two Persian translations of the Azeri Turkish long poem "Haydar Bābāye Salām" by "Shahriyar".

Based on Koller's theory of equivalence (2001) four elements were assigned for the pragmatic equivalence: 1) domestication rather than foreignization, 2) naturalness of the expressions, 3) focus on target-text reader, and 4) content-based product.

Thirty six stanzas from the initial, middle and final part of the poem were selected and then their two Persian translations were analyzed according to the four aforementioned elements. 
Moreover, based on Newmark's ideas (1988) it is also investigated that whether a translation with all the four elements of pragmatic equivalence is a good one or not. According to Newmark's ideas (1988) three markers of a good translation are: 1) utilization of pragmatic equivalence, 2) naturalness, and 3) not sounding like a translation.

More specifically, the present research embarks upon answering the following research questions:

1) Has any of the two translators made use of pragmatic equivalence in translating "Haydar Bābāye Salām" into Persian?

2) Has any of the two translators, utilized pragmatic equivalence more than the other in translating "Haydar Bābāye Salām" into Persian?

3) Has the translator who has utilized pragmatic equivalence more than the other, succeeded in producing a 'better' translation in rendering "Haydar Bābāye Salām" into Persian?

Briefly, the following part of the research includes explanations about: a) the source materials and b) data collection and analysis procedure.

\subsection{Source Materials}

As it was mentioned previously, 36 stanzas of Shahriyar's long poem "Haydar Bābāye Salām" and their two Persian translations were selected to be analyzed according to the markers of pragmatic equivalence. The selected parts are 36 stanzas out of a total of 76 ones from the beginning, the middle, and the final part of the poem. The rationale behind this kind of selection, among others was that the researcher wanted to establish a unified image of the whole poem. In other words, the selected parts seem to be a good representative of the whole poem and their analysis will hopefully give a thorough picture of the entire poem.

The researcher has analyzed the selected stanzas from each part i.e. the initial, middle and the final part of the poem according to the principles of pragmatic equivalence. Two different Persian translations by two different translators: Sarvatian (2002) and Azarpouya (2008) were analyzed in the present research. The translations were in Persian language and in the form of poetry too. These two translations are among the best Persian translations of the poem. Both translators are well known and moreover their mother language is Azeri Turkish.

\subsection{Procedure}

The data collection and analysis of the translations of the selected stanzas in the present research took place in three phases:

In the first stage, thirty six stanzas from the initial, middle and final part of the poem were selected.

Then, at the second step the researcher read the selected original stanzas as well as their corresponding Persian translations thoroughly several times at different time intervals.

And finally at the next stage, the analysis, comparison and evaluation of the stanzas in Azeri Turkish and their relevant Persian renderings were done in order to find out the answers to the research questions. For the analysis of the translations of the source materials, Koller's theory of equivalence (1979) and Newmark's (1988) ideas of a good translation were operationalized and employed.

\section{Findings}

\subsection{Overview}

In this study the researcher has compared and contrasted two different translations of every selected stanza and has described each translation based on the markers of pragmatic equivalence and good translation. As it was mentioned in the previous part, two famous Persian translations of 36 selected stanzas of the long poem of "Haydar Bābāye Salām" were analyzed to discuss their pros and cons according to the criteria determined in this study.

Moreover, the markers of a good translation are investigated in this segment in order to answer the third question of the research. In this study a translation is known to be a good one that involves pragmatic equivalence rather than other equivalences, having naturalness, and not sounding like a translation.

After each stanza is discussed, the results are shown in separate tables for both pragmatic equivalence and good translation. Then, in the last section of the present part, all the findings are presented in certain summary tables in order to give an overall image of the discussions. In the following segments the Persian and Azeri Turkish parts are given according to UN system of transliteration. Due to the space limitations of this article; only six examples, including two for each one of the three parts of the poem have been presented here. Those interested in this research may contact the author for the full version of the research.

\subsection{Results}

In this section the selected stanzas are analyzed according to the markers of pragmatic equivalence. Furthermore, the elements of a good translation which are assigned in the present study are analyzed in the following parts. As it was mentioned before, the stanzas are selected from the initial, middle, and final part of the long poem in order to give an overall image of the whole poem. 


\section{A. Initial Part}

3rd Stanza

Bāyrām ye'lī chārdākhlārī yīkhāndā

Norūz golī, qār chīchakī, chīkhāndā

Āgh būlūtlār koynaklarīn sīkhāndā

Bīzdan bīr yād el'īyīn sāgh olsūn

Dardelarīmīz gouy dīgīlsīn, dāgh olsūn

Translated by (S):

Chon chārtāg rā fekanad bād no bahār

Norūz gholī va qār chīchakī gardad āshkar

Befeshārad abr pīrhane khod beh marghzār

Az mā har ānke yād konad bīgazand bād

Gū: darde mā chon kūh bozorg va boland bād

In this stanza, the concept of foreignization is clearly seen in the second line where the two Azeri Turkish words "Norūz gholī" and "Qar chīchakī" are used instead of their Persian equivalences. Domestication is absent here and the translator has put more emphasis on the language of the poet rather than the target-text reader. So the first and third markers of pragmatic equivalence are absent in this stanza. Except for the foreignized words in the second line, other expressions of the third stanza are natural and familiar in the target language. To explain more, the word "Marghzār" in the third line is a sort of addition which makes the line more natural and understandable for the readers. The whole stanza is contentbased and its content is close to the source one. Therefore, the second and fourth elements of pragmatic equivalence are positive in this stanza.

The first marker of a good translation is absent in this stanza. In other words, the closest natural equivalences are not chosen for all the lines of this stanza. Some lines are natural but the whole stanza not only does not have complete naturalness, but also it sounds like a translation.

Translated by (A):

Bād norūzī cho sāzad ālanakhā rā negūn,

Chon "gole barf” va "gole norūzī” ārad rokh borūn,

Jāme āngah keh chelānand abrhāye barfgūn,

Ānke az mā khaterī rā zendeh dārad, zande bād,

Dardemān chon kūh gardad, dāghemān ākandeh bād.

This stanza is a complete example of domestication rather than foreignization. The translator has effectively chosen the closest natural expressions for the lines of this stanza, and he has made them clearly comprehensible for the target-text reader. So the first and second markers of pragmatic equivalence as well as the third one are positive in this stanza and the whole stanza does not sound like a translation, because of its rhyme and coherence. In the two last lines of the stanza, there are some sorts of addition which make the translation more natural in the target language, but on the other hand, they cause deviation from the source content. The words "Zende bād" and "Ākandeh bād" are the additions which are mentioned above. So the fourth element of pragmatic equivalence is negative here.

As it is explained, the translator has utilized the markers of pragmatic equivalence well. So the stanza can be considered as a good translation because all the three elements of a good translation are positive here and the target text is like an original one.

Table 1. Utilization of the markers of pragmatic equivalence

\begin{tabular}{lllll}
\hline $\begin{array}{l}\text { Stanza } \\
3\end{array}$ & $\begin{array}{l}\text { Domestication rather } \\
\text { than Foriegnization }\end{array}$ & $\begin{array}{l}\text { Complete naturalness } \\
\text { of expressions }\end{array}$ & $\begin{array}{l}\text { Target-text } \\
\text { focused }\end{array}$ & $\begin{array}{l}\text { reader } \\
\text { S }\end{array}$ \\
\hline A & - & + & - & + \\
\hline
\end{tabular}


Table 2. Utilization of markers of a good translation

\begin{tabular}{llll}
\hline Stanza 3 & Pragmatic equivalence & Naturalness & Not Sounding Like a Translation \\
\hline $\mathrm{S}$ & & & \\
\hline $\mathrm{A}$ & - & - & +
\end{tabular}

4th Stanza

Haydar bābā, gūn dālīve dāglāsīn

Ūzūn gūlsūn, būlākhlārevīn āghlāsīn

Ūshākhlarīn bīr dasta gūl bāghlāsīn

Y'el galanda, ver gatersīn būyānā

Balka manīm yatmīsh bakhtīm oyānā

Translated by (S):

Haydar bābā cho dāgh konad poshtat āftāb

Rokhsāre to bekhandad va jūshad ze cheshme āb

Yek daste gol bebandad barāye mane kharāb

Bespār bād rā ke bīyārad be kūye man

Bāshad ke bakht rūy nemāyad be sūye man

In this stanza, all the four elements of pragmatic equivalence are skillfully used by the translator. To explain more, the reader can notice that domestication has priority over foreignization in the present stanza. On the other hand, the translation is in a transparent, fluent and invisible style, and the expressions are really natural in the target language. Target-text reader is the center of concentration and the translator has put more emphasis on his readers' understanding. In order to make his translation more coherent, the translator has omitted the word "Ūshākhlārīn" in the third line and has managed to convey the same content in a good way. Although he has added the word "Kharāb" in the third line, but all in all, the content of his translation is very similar to the original one. Therefore, the target-text readers can understand the translated version as well.

The translated text does not sound like a translation and it is more like an original. It means that all the three markers of a good translation are positive in this stanza. It is fluent and easily comprehensible for the target readers. Therefore, it can be claimed that the utilization of pragmatic equivalence makes the translation a good one.

Translated by (A):

Haydar bābā,

Poshtgarmo dāgh bāshī dar panāhe āftāb,

Chehreh at khandān va cheshme cheshmesārānat por āb,

Kūdakānat dasteī gol chīdeh, bā sad ābo tāb,

Bar sabā deh āvarad kūye kharāb ābade yār,

Balkeh az khāb gerān barkhāst bakhte Shahrīyār.

In this stanza, the translator has completely utilized the elements of pragmatic equivalence and it is a great sample of a good translation according to the markers assigned in the present study. All the expressions are natural in the target language. It means that the main focus of the text is on the target reader. There is no sort of foreignization in this translation and the comprehension of target-text reader has got prime importance. The content is clearly conveyed and the whole stanza does not sound like a translation from the point of view of the coherence. Although there are sorts of addition such as "Bā sad ābo tāb" in the third line and "Kharāb ābāde yār" in the fourth line, but the whole stanza has naturalness in the target language. Therefore, it lacks the characteristics of a translation and does not look like a translated text.

All the three elements of a good translation according to the present study are positive here. So I believe the translator has utilized pragmatic equivalence and he has used natural expressions in the target language. Finally, it seems that the whole stanza is like an original one and the content is the same as the source text. 
Table 3. Utilization of the markers of pragmatic equivalence

Stanza Domestication rather Complete naturalness of Target-text reader Content-based

Table 4. Utilization of markers of a good translation

\begin{tabular}{llll}
\hline Stanza 4 & Pragmatic equivalence & Naturalness & Not Sounding Like a Translation \\
\hline $\mathrm{S}$ & + & + & + \\
\hline $\mathrm{A}$ & + & + & + \\
\hline
\end{tabular}

\section{B. Middle Part}

\section{6th Stanza}

Haydar bābā, būlākhlārīn yārpīzī

Būstānlārīn gūl basarī, gārpīzī

Chīrchīlarīn āgh nābātī, saghghīzī

Îndī da vār dāmāghīmdā, dād ve'rar

İtgīn ge'dan gūnlarīmdan yād ve'rar

Translated by (S):

Az atre pūneha beh labe cheshmeh sārhā

Az hendevāneh, kharbozeh, dar keshtzārhā

Az saghghez va nabat va az īn gūneh bārhā

Māndeh ast ta'm dar dahānam bā chenān asar

Kaz rūz haye gomshode am mīdahad khabar

The first marker of pragmatic equivalence is clearly seen in this stanza. The translator has utilized domestication rather than foriegnization to put more emphasis on the understanding of his target-text reader. As the reader can notice, the third element is also used well here, because the main focus of the translator is on the reader of the text and he has tried to use the closest natural expressions. In other words, there is the priority of message over word by word rendering, so there are some sorts of addition such as "Kharbozeh" in the second line and "Bārhā" in the third line. Therefore, complete naturalness of expressions which is the second marker of pragmatic equivalence is also present here. The content of the target text is conveying the same effect and has the same message as the source text does. As a result, the fourth criterion of the pragmatic equivalence is positive in this stanza and it is content-based.

It can be claimed that the present stanza is a good translation because all the three elements of a good translation are seen here i.e. the translator has utilized pragmatic equivalence greatly; the lines of translation are natural and the whole stanza does not sound like a translation and it is more similar to the original one.

Translated by (A):

Pūnehaye cheshmeh sārān, nāmehye peyke bahār,

Sar be sare jālīzhā por hendevāneh vo khīyār,

Saghghezo noghlo nabāte pīleh varhāye dīyār,

Mītarāvad ta'meshān peyvasteh dar kāmam hanūz,

Yādegārī māndeh zān gomgashteh ayyāmmam hanūz. 
This stanza is a great sample of utilizing pragmatic equivalence, because all four elements are present here and the translator has successfully used domestication and complete natural expressions, as well as focusing on target-text reader and conveying the same content in his translation. Ease of comprehension is one of the important features of this stanza and it creates the amicable feelings for the great natural beauty of the birthplace of the poet. The translator has added some words such as "Peyke bahār" and "Noghl" which have positive sense in the target language and they help the reader of the target text to communicate well with the translated text.

On the other hand, it does not sound like a translation because it seems that all the markers of a good translation were skillfully used and the lines of the target-text have naturalness in the target language.

Table 5. Utilization of the markers of pragmatic equivalence

\begin{tabular}{lllll}
\hline $\begin{array}{l}\text { Stanza } \\
26\end{array}$ & $\begin{array}{l}\text { Domestication rather } \\
\text { than Foriegnization }\end{array}$ & $\begin{array}{l}\text { Complete naturalness of } \\
\text { expressions }\end{array}$ & $\begin{array}{l}\text { Target-text } \\
\text { reader focused }\end{array}$ & Content-based \\
\hline S & + & + & + & + \\
\hline & & & & + \\
\hline
\end{tabular}

Table 6. Utilization of markers of a good translation

\begin{tabular}{llll}
\hline Stanza 26 & Pragmatic equivalence & Naturalness & Not Sounding Like a Translation \\
\hline S & & & + \\
\hline & + & + & \\
A & + & + & + \\
\hline
\end{tabular}

\section{8th Stanza}

Shāl īsteh dīm mandah e'vdah āghlādīm

Bīr shāl ālīp, te'z be'līmeh bāghlādīm

Golām gīleh gāshdīm, shālī sāllādīm

Fātemeh khālā mana jūrāb bāghlādī

Khān nanamī yādā sālib, āghlādī

Translated by (S):

Bā gerye khāstam keh haman shab ravam be bām

Shālī gerefteh bastam va raftam be vaqte shām

Āvīkhteh ze rozaneye khāneye Golām

Jūrāb basto dīdāmesh ān shab ze rozaneh

Begerīst khāle Fātemeh bā yāde khān nana

There is no foreign word in this stanza except the last line and the word "Khān nana" which is not unfamiliar in the target language. So the first element i.e. domestication is positive in this stanza. The present stanza is about the custom which is known and popular in the birthplace of the poet. So the word by word rendering of the expressions cannot make it comprehensible for the target-text readers. For this reason, the expressions do not seem like natural and they do not have naturalness like the original one. It is not target-text reader focused neither, because the statements and expressions are more source-text oriented and they are not easily comprehensible for the target reader. The content of the source text is not conveyed well in the target text. The reason is that the translator has put more emphasis on the form rather than the message.

According to the markers of a good translation, the present stanza does not look like a good one. It can be noticed that the present stanza doesn't seem to be like the original and it has the color of translation within its lines. In other words, it lacks naturalness and coherence because of the unfamiliar word and custom which are used by the translator according to the source text. 
Translated by (A):

Bahre shālī khod rā geryāno nālān sākhtam,

Tā gereftam, bar kamar pīchīdeh, bīrūn tākhtam,

Raft az bām Golām ān rā fūrū andākhtam,

Khāleh jānam "Fātemeh" bar shāle man jūrāb bast,

Yāde "khānīm nane" am jāno delash rā sakht khast.

In this stanza, domestication has priority over foriegnization and the translator has tried to choose the closest natural equivalences. Therefore, the first marker of pragmatic equivalence is positive here. On the other hand, the expressions have an acceptable coherence and naturalness in the target language. It means that target readers are able to understand the meaning of the expressions, and the text is translated according to the concentration on readers' understanding, but the content is different from the meaning of the original. The message of the source text reminds the readers of an old custom, but it is not the same in the target-text. So, the translation is not content-based.

From the point of view of a good translation, the text has naturalness and utilization of pragmatic equivalence is positive. On the other hand it is not like a translation and the target text reader seems to be able to read and communicate with the translated text like an original one.

Table 7. Utilization of the markers of pragmatic equivalence

\begin{tabular}{|c|c|c|c|c|}
\hline $\begin{array}{l}\text { Stanza } \\
28\end{array}$ & $\begin{array}{l}\text { Domestication rather } \\
\text { than Foriegnization }\end{array}$ & $\begin{array}{l}\text { Complete naturalness of } \\
\text { expressions }\end{array}$ & $\begin{array}{l}\text { Target-text reader } \\
\text { focused }\end{array}$ & Content-based \\
\hline S & + & - & - & - \\
\hline A & + & + & + & + \\
\hline
\end{tabular}

Table 8. Utilization of markers of a good translation

Stanza Pragmatic equivalence Naturalness Not Sounding Like a Translation

28

$\mathrm{S}$

$-$

A

$+$

$+$

$+$

\section{Final Part}

52nd stanza

Haydar bābā, qara kūlūn dara sī

Khashangnābīn yolī, bandī, barasī

Ordā doshīr chīl kahlīgīn fara sī

Ordān ge'char yūrdūmūzūn ozoneh

Bīzdah ge'chak yūrdūmūzūn sozoneh

Translated by $(\mathrm{S})$ :

Dar darreyye qara kūl va dar rāhe Khashangnāb

Dar sakhrehā va kabke godārān va bande āb

Kabkān khāldār zarī kardeh jāye khāb

Ze ānja cho bogzarīd zamīnhāye khāke māst

In qessehā barāye khāke pāke mast 
In the very first line of this stanza, the Turkish statement "Qara kül" is a clear evidence of foreignization and it is a Turkish word which was exactly used in Persian translation. So the translator has not utilized the first element of pragmatic equivalence. In the second line of the translated version, the word "Kabke godārān" is a sort of addition and it makes the line not like an original one. In other words, complete naturalness of expressions is not seen here and the second marker of pragmatic equivalence is absent as well. Furthermore, because domestication is not utilized, I can claim that it is not target-text reader focused and the translator has put more emphasis on the original author rather than the reader of the target text and his comprehension. The last two lines are very well comprehensible in the target language and they convey the same content as well as the source text. Therefore the forth marker of pragmatic equivalence is clearly seen in the translation.

From the point of view of a good translation, this stanza is weak in utilizing pragmatic equivalence, being natural, and sounding like a translation. Because of the reasons mentioned above, it does not score well in this regard. Therefore, the present stanza is more like a translation rather than being like an original one.

Translated by (A):

Haydar bābā,

Darreyye zībāye "meshgīn būteh", por kūho kamar,

Rāho bande Khoshgnāb ast va gozargāhe safar,

Jūjehāye kabk mīyoftand dar ān rahgozar,

Az hamān ja bogzarad rāhe dehe zībāye mā,

Mā ham az īn rāh sar āghazīm vasfe rūstā

In this stanza, the translator has utilized the first marker of the pragmatic equivalence, i.e. domestication. In the very first line of the stanza the translator has translated the statement "Qara kūl" into "Meshgīn būteh" and it is mere domestication. It also lacks foreignization and the second marker of pragmatic equivalence i.e. the complete naturalness of the expression is clearly seen. Furthermore, because domestication is utilized, it can be claimed that it is target-text reader focused and the translator's more emphasis is on the understanding of the target text reader rather than the exact content of the original poem. In other words, the translator has focused on the perception of the target reader in order to make his translation tangible in the target language. Thus, he has succeeded in utilizing the third marker of pragmatic equivalence. The content of the translated text is so similar to the original one and the last element of the pragmatic equivalence seems to be positive here.

Moreover, the translation is natural and it does not sound like a translation. It can be said that the translator has utilized the markers of a good translation according to the present study. The translated text seems like an original and it does have the characteristics of a translation. It means that the natural expressions make it more like an original poem rather than a translated text.

Table 9. Utilization of the markers of pragmatic equivalence

\begin{tabular}{|c|c|c|c|c|}
\hline $\begin{array}{l}\text { Stanza } \\
52\end{array}$ & $\begin{array}{l}\text { Domestication rather } \\
\text { than Foriegnization }\end{array}$ & $\begin{array}{l}\text { Complete naturalness of } \\
\text { expressions }\end{array}$ & $\begin{array}{l}\text { Target-text reader } \\
\text { focused }\end{array}$ & Content-based \\
\hline S & - & - & - & + \\
\hline A & + & + & + & + \\
\hline
\end{tabular}

Table 10. Utilization of markers of a good translation

\begin{tabular}{lllc}
\hline Stanza 52 & Pragmatic equivalence & Naturalness & Not Sounding Like a Translation \\
\hline $\mathrm{S}$ & - & - & - \\
\hline $\mathrm{A}$ & + & + & + \\
\hline
\end{tabular}


Majdolsādāt gūlard̄̄ bāghlār kīmī

Gūrūllādārdī būlūtī dāghlār kīmī

Soz āghzīndā arīrdī yāghlār kīmī

Ālnī āchīgh, yākhshī darīn qānārdī

Yāshīl gozlar chīrākh takīn yānārdī

Translated by (S):

Majdolsādāt khandeh khosh mīzanad cho bāgh

Chon abre kūhsār beghorrad beh bāgho rāgh

Harfash zolālo roshan chon roghane cherāgh

Bā jabhate goshādeh, kheradmande dīh būd

Cheshmāne sabze ū be zomorrod shabīh būd

In the present stanza, the translator has tried to minimize the foreignness of the target text in order to create more transparent and fluent text for the target readers. So it can be said he has utilized domestication rather than foreignization in his translation. In other words, there is no foreign word in the Persian translation and I believe that the usage of domestication can be observed clearly in this stanza. So the first marker of the pragmatic equivalence seems to be positive here. But it can be claimed that the expressions of the target text are not like the natural ones in the original text. In other words, they lack complete naturalness, and also they do not sound like the fluent original expressions. The reason is that the whole stanza does not have coherence like an original poem, and this lack of coherence is clearly observed in between the first and second lines as well as the fourth and fifth lines. It seems to me that the main reason of the aforementioned problem is unnatural expressions of the translation which make it more like a translation. On the other hand, it can be claimed that the target text is not a receiver-oriented one because it is more form-based and the translator has tried to render a word-by-word translation. I believe that the faithfulness to the original writer has received prime importance; therefore, the text is not a receiver oriented one. It means that the third element of the pragmatic equivalence is negative here. It seems that the content of the target text is to a large amount similar to the source one. Therefore, the third marker of the pragmatic equivalence seems to be present in this stanza.

According to the markers of a 'good translation' the present stanza lacks the determined elements in this study. It can be claimed that the translator has not utilized the pragmatic equivalence in his translation because of the reasons mentioned in the previous paragraph. I believe that the target text is more like a translation and it does not sound like an original one. In other words, the characteristics of the translation such as lack of transparency and also absence of fluency are present in this stanza, and they make it more like a translation rather than an original poem. Therefore, all the three markers of a 'good translation' can be regarded as being negative here.

Translated by (A):

“Majdosādāt" ān ke khandān būd hamchon būstān,

Gāh, cho qollehāye abr andūdeh, ghorrāno zhīyān,

$\bar{A} \mathrm{~b}$ mīshod hamcho roghan, harfhāyash dar dahan

Būd pīshānī bolando zharfbīno dīdeh pāk

Cheshmhāye sabzgūnash chon cherāghī tābnak.

The present stanza is the distinct sample of the domestication. It means that, there is no foreign word in the translation and the translator has tried to choose the closest natural equivalences for the expressions of the text. It means that the domestication is utilized rather than foreignization in this stanza, and the first marker of the pragmatic equivalence is positive here, in addition, it seems that the expressions of the translation are very natural. In other words, it can be assumed that they are common and familiar in the target language. It is also to say that the translator has used natural expressions in his translation in order to make the target text comprehensible for the target readers. I believe that it is possible for the target reader to communicate with the target text and the familiar expressions make the text easy to comprehend. It can be said that the target text is receiver-oriented and the translator has focused on his readers' comprehension. Therefore, the second and the third elements of the pragmatic equivalence are present in this stanza. In the present researcher's view, one of the brilliant features of this stanza translated by (A) is the accurate conveyance of the content. The message of the source text is effectively carried into the target text and the translator has transmitted the same meaning in his translation. Finally, the fourth element of the pragmatic equivalence which is known as content-based is positive. 
The present researcher believes that this stanza has the markers of a 'good translation' which are utilized in the present study. It is to say that the translator has successfully utilized the pragmatic equivalence in his translation according to the explanations mentioned above. Moreover, the target text is more like the original poem rather than a translation, so it seems that the expressions have complete naturalness and also it can be claimed that the text is fluent and transparent in the target language. Therefore, it can be concluded that all the three markers of a good translation are positive in this stanza.

Table 11. Utilization of the markers of pragmatic equivalent

\begin{tabular}{llllll}
\hline $\begin{array}{l}\text { Stanza } \\
56\end{array}$ & $\begin{array}{l}\text { Domestication rather } \\
\text { than Foriegnization }\end{array}$ & $\begin{array}{l}\text { Complete naturalness of } \\
\text { expressions }\end{array}$ & $\begin{array}{l}\text { Target-text } \\
\text { focused }\end{array}$ & reader & Content-based \\
\hline & & & - & + \\
\hline $\mathrm{S}$ & + & + & + & + \\
$\mathrm{A}$ & + & + & + & + \\
\hline
\end{tabular}

Table 12. Utilization of markers of a good translation

\begin{tabular}{llll}
\hline $\begin{array}{l}\text { Stanza } \\
56\end{array}$ & Pragmatic equivalence & Naturalness & Not Sounding Like a Translation \\
& & & - \\
$\mathrm{S}$ & - & - & \\
\hline & & + & + \\
$\mathrm{A}$ & + & + &
\end{tabular}

\subsection{Discussion}

In this section, all the findings of the previous part are summarized in the tables in order to give a thorough overview of the discussions. With the help of these tables, it can be claimed that which translator has utilized the markers of pragmatic equivalence more than the other according to the present research. Also it can be concluded that whether a translation which has utilized pragmatic equivalence is a better one than the other or not.

Table 1. Frequency of positive and negative scores on pragmatic equivalence in the first 12 stanzas

\begin{tabular}{|c|c|c|}
\hline Translator & Positives & Negatives \\
\hline $\mathrm{S}$ & 26 & 22 \\
\hline A & 34 & 14 \\
\hline
\end{tabular}

Table 2. Frequency of positive and negative scores on pragmatic equivalence in the second 12 stanzas

\begin{tabular}{|c|c|c|}
\hline Translator & Positives & Negatives \\
\hline $\mathrm{S}$ & 26 & 22 \\
\hline A & 26 & 22 \\
\hline
\end{tabular}

Tables 3. Frequency of positive and negative scores on pragmatic equivalence in the third 12 stanzas

\begin{tabular}{|c|c|c|}
\hline Translator & Positives & Negatives \\
\hline $\mathrm{S}$ & 30 & 18 \\
\hline A & 35 & 13 \\
\hline
\end{tabular}

Table 4. Total positive and negative scores on pragmatic equivalence

\begin{tabular}{lll}
\hline Translator & Total Positives & Total Negatives \\
\hline $\mathrm{S}$ & 82 & 62 \\
\hline $\mathrm{A}$ & 95 & 49 \\
\hline
\end{tabular}


As it was explained in details in the above tables, positive markers of pragmatic equivalence for the translator $\mathrm{A}$ is more than the translator S. It means that he has succeeded in the utilization of the elements of pragmatic equivalence more than the other translator. In other words, translation of Azarpouya has more domestication rather than foreignization in comparison to the translation of Sarvatian. It is also more reader-focused and the expressions are natural like in his translation. Moreover, the translated text by Azarpouya is more content-based according to the present research. The overall results of the discussions according to the elements of a good translation are given in the following tables:

Table 5. Frequency of positive and negative scores on a good translation in the first 12 stanzas

\begin{tabular}{|c|c|c|}
\hline Translator & Positives & Negatives \\
\hline $\mathrm{S}$ & 20 & 16 \\
\hline A & 2 & 13 \\
\hline
\end{tabular}

Table 6. Frequency of positive and negative scores on a good translation in the second 12 stanzas

\begin{tabular}{llll}
\hline & Translator & Positives & Negatives \\
\hline $\mathrm{S}$ & & 15 & 21 \\
\hline $\mathrm{A}$ & 15 & & 21 \\
\hline
\end{tabular}

Table 7. Frequency of positive and negative scores on a good translation in the third 12 stanzas

\begin{tabular}{|c|c|c|}
\hline Translator & Positives & Negatives \\
\hline $\mathrm{S}$ & 18 & 18 \\
\hline A & 18 & 18 \\
\hline
\end{tabular}

Table 8. Total positive and negative scores on a good translation

\begin{tabular}{lll}
\hline Translator & Total Positives & Total Negatives \\
\hline $\mathrm{S}$ & 53 & 55 \\
\hline $\mathrm{A}$ & 56 & 52 \\
\hline
\end{tabular}

As it is observed, the total number of the positive markers of a good translation according to the present study is higher for translator (A). It means that he has utilized the elements of a good translation more in comparison to the other translator. According to this research, the Persian translation of the Azeri Turkish long poem "Haydar Bābāye Salām" by Azarpouya has utilized pragmatic equivalence more than Sarvatian. It can also be claimed that translation of Azarpouya is more natural like and it does not sound like a translation. However, it should be mentioned that the differences between the numbers of positive scores in two translations is very low and they are very close to each other (56 vs. 53). But all in all, Azarpouya has produced a better translation according to the criteria of a good translation utilized in the present study.

Finally, it should be restated that, the present study was limited only to 36 stanzas from the beginning, middle, and end part of the poem. Therefore, the generalization of the finding is limited to only these stanzas. In addition, as the data above revealed, since the difference between the two translations were not very significant, therefore generalizations on the basis of the present findings should be done with caution.

\section{Conclusion}

\subsection{Overview}

"Haydar Bābāye Salām" (Greetings to Haydar Bābā) is a post-world war II Azeri Turkish poetry written by an Azeri famous poet Shahriyar, and it was first published in Tabriz in 1956. It is written in colloquial Azeri Turkish, and reflects the rustic and simple village life of the author in bygone years. The poem is known as a great masterpiece in Azeri Turkish language and it plays an effective role in the linguistics and poetic culture of the source language.

Therefore, the present researcher decided to analyze two famous Persian translations of this great Azeri Turkish masterpiece according to the elements of pragmatic equivalence as operationalized in the present research.

Furthermore, the present researcher has tried to find out which one the translators, was more successful in conducting this challenging endeavor. To sum up, content analysis of the original Shahriyar's poem as well as the corresponding translated versions plus the evaluation of the results in the present study, lead to the following conclusions. 
As presented and discussed in the previous part of the research it was found that the translation by Azarpouya (1387) has succeeded in utilizing the markers of pragmatic equivalence more than the other translation by Sarvatian (1381). Therefore it can be claimed that Azarpouya has produced a better translation according to the factors operationalized in this research. In other words, Azarpouya has utilized domestication rather than foreignization more than the other translator, and also his expressions are more natural according to the criteria of the present research.

In order to answer the first research question, we may claim that both translators have utilized the elements of pragmatic equivalence to some extent. But there are certain differences in their extent of utilization. It means that one of the translators has adopted more elements than the other, which is explained and discussed in the following paragraph.

Regarding the second research question of the study, the translation by Azarpouya has the features of pragmatic equivalence more than the translation of Sarvatian. It means that Azarpouya has utilized the markers of pragmatic equivalence in his translation rather than other kinds of equivalences. His translation is target-reader focused according to the analysis discussed in the previous part of the research. On the other hand, his translation is also more contentbased and he has given more priority to the message rather than the form in comparison to the translation by Sarvatian.

In order to answer the third question of the present study, characteristics of a good translation are also analyzed. The results show that the translation of Azarpouya is a better one in comparison to the other translation according to the criteria of a good translation adopted in the present study. It can be concluded that the translator who has utilized pragmatic equivalence more than the other one has also produced a better translation concerning the third question of this study.

Consequently, it can be claimed that when the translator of a literary work chooses the pragmatic equivalence for his translation process, he is more likely to succeed in creating a good translation rather than the other translators who do not utilize this certain type of equivalence.

Moreover, the results of the present research show that the translation which is based on pragmatic equivalence is more natural like and it does not have the color of translation. In other words, the pragmatic equivalence approach results in a naturalness of the expressions of the translated text.

Overall, according to the findings of the present research pragmatic equivalence can be considered as an appropriate approach in poetry translation.

\section{References}

Baker, M. (1997). The Routledge Encyclopedia of Translation Studies, Part II; History and Traditions. London and New York: Routledge.

Baker, M. (1992). In other words: A Course on Translation. London and New York: Routledge.

Chesterman, A. (1997). Memes of Translation. Philadelphia: john Benjamins.

Classe, O. (Ed.). (2000). The Encyclopedia of Literary Translation into English. London: Fitzroy Dearbon

Deedari, R. \& Mansouri, M.(2005). Understanding Poetry. Tehran: Rahnama Press.

Faghih, E. (2006). Translation problems and prospects of definition. Translation Studies, 4(14). 29-46.

Halliday, M.A.K. and C. Mathiessen (1999). Constructing Experience Through Meaning. London: Cassell, 657.

Hatim, B., \& Munday, J. (2004). Translation, an advanced resource book. New York: Routledge.

Hermans, T. (2000) Translation in systems. Descriptive and Systematic Approaches Explained. Manchester: St Jerome.

Holmes, J. S. (Ed.). (2000). The Nature of Translation: Essay on the Theory and Practice of literary Translation. The Hague: Mouton.

Jackson, R. (2003). From Translation to Imitation. London: George Allen and Unwin LTD.

Herzfeld, M. (2003). The unspeakable in pursuit of the ineffable: representations of untranslatability in ethnographic discourse. In P. G. Rubel \& A. Rosman (Eds.), Translating culture: perspectives on translation and anthropology. Oxford: Oxford University Press.

Koller,W. (1989). Equivalence in Translation theory: translated from German by A. Chesterman, in A. Chesterman (ed.), pp. 99-104.

Kopp, M. (1998). Poetry in Translation. London and New York: Routledge.

L. Larson, M. (1998). Meaning-Based Translation. America: University Press.

Munday, J. (2001). Introducing Translation Studies, theories and applications. New York: Routledge Publications.

Newmark, P. (1988). A Textbook of Translation. New York and London: Prentice-Hall, International (UK) Ltd.

Nida, E. (1964). Towards a Science of Translating. Leiden: E.J. Brill.

Pym, A. (2007). Natural and Directional Equivalence in Theories of Translation. The Metalanguage of Translation, Gambier, Yves and Luc van Doorslaer(eds),271- 294. 
Venuti, L. (2001). The Translator's Invisibility: A History of Translation. London and New York: Routledge.

Wilss, W (1982). The Science of Translation: Problems and Methods. Tubingen: Gunter Narr Verlag.

$$
\begin{aligned}
& \text { بهحت تبريزى، (1387)، حيدر بابايا سلام، جابٍ بسيت و دوم، تهران: انتشار ات نحاه. }
\end{aligned}
$$

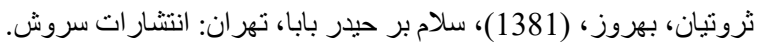

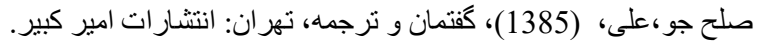

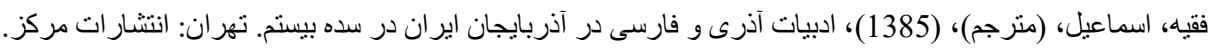

